\title{
MEKANISME IDEAL PENYELESAIAN SENGKETA ADAT DI BALI SESUAI DENGAN KONSEP KEKINIAN ${ }^{1}$
}

Oleh :

\author{
I Wayan Arta Ariawan ${ }^{2}$
}

\begin{abstract}
Based on the data from Bali Regional Police (2014) appear that a lot of custom disputes unfinished effectively thus create some question : (1) what is the factor that influencing effectiveness of solving custom dispute? How is an ideal mechanism for solving custom dispute in Bali according to the contemporary concept? That question is becoming a problem in this script. Since the problem reviewed normatively, indentified some factors that influencing not effectively solving custom dispute, there are (a) law factor that not sufficient yet. (b) law implementer factor with a weak skill and quality in solving the custom dispute.; (c) the supporting of tool and facility factor is not sufficient yet; and (d) society factor who is ignoring the values of custom law; (e) value of society cultures that start shifting, leaving togetherness and glorifying individualistic. About an ideal mechanism for solving accustom dispute in Bali according to contemporary concept, result of the solution conclude that the most accurate of solving custom dispute through internal mechanism based on local wisdom. But, if an internal mechanism failed, then solving of custom dispute can do by using an external mechanism, that is solving of custom dispute which doing by Government with forward an exist custom regulation and /or social regulation and the existence of all is recognized. In the case of this mechanism failed, then conflict solution done by the unit of solving social conflict task that established by government.
\end{abstract}

Key word : custom dispute, solving of dispute mechanism, effectiveness of solving the dispute.

\footnotetext{
Abstrak

Berdasarkan data yang dihimpun Kepolisian Daerah Bali (2014) tampak bahwa banyak sengketa adat yang tidak dapat diselesaikan secara efektif sehingga timbul pertanyaan: (1) apakah faktor-faktor yang mempengaruhi efektivitas penyelesaian sengketa adat? (2) bagaimanakah mekanisme ideal penyelesaian sengketa adat di Bali yang sesuai dengan konsep kekinian? Pertanyaan itulah yang menjadi permasalahan dalam tulisan ini. Setelah permasalahan tersebut dikaji secara normatif, diidentifikasi beberapa faktor yang mempengaruhi tidak efektifnya penyelesaian sengketa adat, yaitu (a) faktor hukumnya yang belum memadai; (b) faktor pelaksana hukum yang kemampuan dan kualitasnya masih lemah dalam penyelesaian sengketa adat; (c) faktor sarana dan fasilitas pendukung yang kurang memadai; serta (d) faktor masyarakat yang mengabaikan nilai-nilai

Artikel ini merupakan karya ilmiah mahasiswa pada Program Studi Magister (S2) Ilmu Hukum Program Pascasarjana Universitas Udayana, serta mengucapkan terimakasih kepada Prof. Dr. Tjok Istri Putra Astiti, SH.,MS dan Dr. Ni Nyoman Sukerti, SH.,MH selaku Pembimbing Tesis.

2 Mahasiswa magister ilmu hukum Universitas Udayana, Denpasar, Bali, email: wayan.arta.ariawan@ gmail.com
} 
hukum adat; serta (e) nilai-nilai budaya masyarakat yang mulai bergeser, yang mulai meninggalkan nilai-nilai kebersamaan dan mengagungkan nilai-nilai individualistik. Mengenai mekanisme yang ideal dalam menyelesaikan sengketa adat di Bali sesuai dengan konsep kekinian, hasil pembahasan menyimpulkan bahwa penyelesaian yang paling tepat adalah penyelesaian sengketa adat melalui mekanisme internal berbasis kearifan lokal. Tetapi, apabila mekanisme internal tersebut tidak berhasil, maka penyelesaian sengketa adat dapat dilakukan dengan menggunakan mekanisme eksternal, yaitu penyelesaian sengketa adat dilakukan oleh Pemerintah dengan mengedepankan Pranata Adat dan/atau Pranata Sosial yang ada dan diakui keberadaannya. Dalam hal mekanisme inipun gagal, maka penyelesaian konflik dilakukan oleh Satuan Tugas Penyelesaian Konflik Sosial. yang dibentuk oleh Pemerintah.

Kata kunci: sengketa adat, mekanisme penyelesaian sengketa, efektivitas penyelesaian sengketa.

\section{PENDAHULUAN}

\subsection{Latar Belakang}

Kehidupan masyarakat Bali dewasa ini sangat kompleks, penuh persaingan dan konflik dengan orientasi hidup yang bersifat materialistik, politik kekuasaan dan kepuasan duniawi lainnya ${ }^{3}$.
Berdasarkan data kasus konflik sosial tahun 2014 di jajaran Polda Bali, sebagaimana Tabel 1 sebagai berikut :

Tabel 1

Data Kasus Konflik Sosial Tahun 2014 Jajaran Polda Bali

\begin{tabular}{|c|c|c|c|c|c|c|c|c|c|c|c|c|}
\hline \multirow{3}{*}{ NO } & \multirow{3}{*}{ SATUAN WILAYAH } & \multicolumn{8}{|c|}{ SUMBER KONFLIK } & & & \multirow{3}{*}{ SISA } \\
\hline & & \multicolumn{2}{|c|}{ POLEKSOSBUD } & \multicolumn{2}{|c|}{ SARA } & \multicolumn{2}{|c|}{$\begin{array}{c}\text { BATAS } \\
\text { WILAYAH }\end{array}$} & \multicolumn{2}{|c|}{$\begin{array}{c}\text { SUMBER } \\
\text { DAYA ALAM }\end{array}$} & \multicolumn{2}{|c|}{ TOTAL } & \\
\hline & & $\mathrm{JML}$ & SAl & $J M L$ & SAl & $\mathrm{JML}$ & SAl & JML & SAl & JML & SAl & \\
\hline 1 & POLRESTA DENPASAR & 2 & - & 2 & - & 2 & - & - & - & 6 & - & 6 \\
\hline 2 & POLRES BADUNG & 2 & - & 2 & - & 1 & - & - & - & 5 & - & 5 \\
\hline 3 & POLRES BULELENG & 2 & 1 & 2 & 2 & - & - & 1 & - & 5 & 3 & 2 \\
\hline 4 & POLRES TABANAN & 1 & 1 & - & - & 2 & - & - & - & 3 & 1 & 2 \\
\hline 5 & POLRES GIANYAR & 3 & - & - & - & 3 & - & - & - & 6 & - & 6 \\
\hline 6 & POLRES KLUNGKUNG & 2 & - & - & - & 1 & - & - & - & 3 & - & 3 \\
\hline 7 & POLRES BANGLI & 1 & - & 1 & - & 1 & - & - & - & 3 & - & 3 \\
\hline 8 & POLRES KARANGASEM & 1 & - & - & - & 2 & - & - & - & 3 & - & 3 \\
\hline 9 & POLRES JEMBRANA & 1 & 1 & - & - & - & - & - & - & 1 & 1 & - \\
\hline & JUMLAH & 15 & 3 & 7 & 2 & 12 & - & 1 & - & 35 & 5 & 30 \\
\hline
\end{tabular}

Sumber : Dikutip Dari Data Kasus Konflik Sosial Bulan Maret Tahun 2014 Biroops Polda Bali

\footnotetext{
I Ketut Sudantra, 2010, "Peranan Desa Pakraman Dalam Penyelesaian Perkara di Luar Pengadilan". Dalam Wicara Lan Pamidanda, Editor I Ketut Sudantra, dan A.A. Gede Oka Parwata, Udayana U, Datniversity Press, Denpasar, hlm. 27.
} 
Berdasarkan data Tabel 1 di atas, diketahui bahwa di semua satuan wilayah Polda Bali, terdapat konflik sosial baik yang bersumber dari masalah politik, ekonomi, sosial, dan budaya (Poleksosbud), konflik yang bersumber dari SARA, perebutan batas wilayah, maupun perebutan sumber daya alam. Sampai dengan tahun 2014, dari semua sumber konflik tersebut di atas, hanya 5 (lima) konflik sosial yang dapat diselesaikan. Berdasarkan data sengketa adat dari Polda Bali, diketahui bahwa: sebanyak 6 kasus. Berdasarkan data Tabel 1 di atas, terkait dengan data kasus konflik sosial tahun 2014 jajaran Polda Bali, dapat diketahui bahwa dari semua sumber konflik tersebut di atas, telah terjadi 35 (tiga puluh lima) kasus konflik sosial di seluruh Bali. Dari seluruh konflik sosial tersebut, hanya 5 (lima) konflik sosial yang dapat diselesaikan, yaitu konflik sosial di wilayah hukum Polres Buleleng sebanyak 3 (tiga) kasus, dan masingmasing 1 (satu) kasus di wilayah hukum Polres Tabanan dan Polres

Tabel 2

Data Kasus Sengketa Adat s/d Tahun 2014 di Jajaran Polda Bali

\begin{tabular}{|c|c|c|c|c|c|}
\hline \multirow[b]{2}{*}{ NO } & \multirow[b]{2}{*}{ SATUAN WILAYAH } & \multicolumn{3}{|c|}{ SUMBER SENGKETA } & \multirow{2}{*}{ TOTAL } \\
\hline & & PERMASALAHAN ADAT & $\begin{array}{c}\text { PEMEKARANDESA } \\
\text { PAKRAMAN }\end{array}$ & $\begin{array}{l}\text { TAPAL } \\
\text { BATAS }\end{array}$ & \\
\hline 1 & POLRES GIANYAR & 6 & 1 & 1 & 8 \\
\hline 2 & POLRES BADUNG & 4 & - & 1 & 5 \\
\hline 3 & POLRES TABANAN & 1 & 1 & 3 & 5 \\
\hline 4 & POLRES KR. ASEM & 2 & 1 & 1 & 4 \\
\hline 5 & POLRES BANGLI & 4 & - & - & 4 \\
\hline 6 & POLRESTA DENPASAR & 3 & - & - & 3 \\
\hline 7 & POLRES BULELENG & - & 1 & - & 1 \\
\hline 8 & POLRES KLUNGKUNG & 1 & - & - & 1 \\
\hline 9 & POLRES JEMBRANA & 1 & - & - & 1 \\
\hline & JUMLAH & 22 & 4 & 6 & 32 \\
\hline
\end{tabular}

Sumber : Dikutip dari Data Pemetaan Permasalahan Adat, Tapal Batas Dan Pemekaran Desa Pakraman di Provinsi Bali, oleh Dit Intelkam Polda Bali 2014

Dari Tabel 2 diketahui bahwa sampai dengan tahun 2014 terdata telah terjadi 32 (tiga puluh dua) sengketa adat di seluruh Bali. Sumber terjadinya sengketa disebabkan oleh permasalahan adat sebanyak 22 kasus, pemekaran desa pakraman sebanyak 4 kasus dan permasalahan tapal batas
Jembrana. Di wilayah hukum Polres Kota Denpasar sampai dengan tahun 2014 terjadi 6 (enam) konflik sosial, namun tidak ada kasus yang mampu diselesaikan. Di wilayah hukum Polres Badung sampai dengan tahun 2014 terjadi 5 (lima) konflik sosial, namun tidak ada kasus yang mampu 
diselesaikan. Hal serupa juga terjadi di wilayah hukum Polres Gianyar, Klungkung, Bangli, dan Karangasem. Berdasarkan data pada Tabel 1 di atas, diketahui bahwa dari 35 (tiga puluh lima) kasus konflik sosial yang terjadi di Bali, hanya 5 (lima) kasus yang mampu diselesaikan.

Uraian di atas menunjukkan bahwa sampai dengan tahun 2014 peran Pemerintah dan instansi terkait dalam rangka penyelesaian sengketa adat masih belum maksimal, sehingga perlu dilaksanakan penelitian dan kajian terkait dengan upaya memaksimalkan peran Pemerintah dan instansi terkait dalam rangka penyelesaian sengketa adat di Bali. Penting diidentifikasi faktor-faktor yang mempengaruhi efektifitas penyelesaian sengketa adat tersebut, sehingga dapat dirumuskan mekanisme ideal penyelesaian sengketa adat tersebut.

\subsection{Perumusan Masalah}

Berdasarkan latar belakang masalah sebagaimana di atas, permasalahan yang akan dikaji dalam penelitian ini adalah sebagai berikut:

1. Apakah faktor-faktor yang mempengaruhi efektivitas penyelesaian sengketa adat di Bali ?

2. Bagaimanakah mekanisme ideal penyelesaian sengketa adat di Bali yang sesuai dengan konsep kekinian?

\subsection{Tujuan Penelitian}

Tujuan dari penelitian ini adalah untuk mengetahui dan menganalisa faktor-faktor yang mempengaruhi efektivitas penyelesaian sengketa adat dan mekanisme ideal penyelesaian sengketa adat di Bali sesuai dengan konsep kekinian.

\section{METODE PENELITIAN}

Penelitian ini menggunakan metode penelitian hukum normatif, karena permasalahan dalam penelitian ini dipecahkan berdasarkan normanorma hukum yang berlaku ${ }^{4}$. Pendekatan yang digunakan adalah pendekatan perundang-undangan dan pendekatan konseptual.

Sebagai penelitian hukum normatif, bahan-bahan yang digunakan dalam penelitian ini meliputi bahan hukum primer dan bahan hukum sekunder. Bahan hukum primer yang digunakan adalah bahan hukum yang bersifat otoritatif dan mempunyai kekuatan mengikat, ${ }^{5}$ terdiri dari peraturan perundang-undangan yang relevan (seperti: UU RI Nomor 7 tahun 2012 tentang Penanganan Konflik Sosial) maupun petunjukpetunjuk teknis penyelesaian sengketa adat yang dieluarkan oleh lembaga adat (Keputusan Majelis Utama Desa Pakraman Bali Nomor : 002/Skep/

\footnotetext{
$4 \quad$ Mukti Fajar ND dan Yulianto Achmad, 2010, Dualisme Penelitian Hukum Normatif \& Empiris, Pustaka Pelajar, Yogyakarta, hlm. 36-37.

5 Peter Mahmud Marzuki, 2013, Penelitian Hukum, Edisi Revisi, Kencana Prenada Media Group, Jakarta, hlm. 181
} 
MDP Bali/IX/2011 tentang Petunjuk Pelaksanaan dan Petunjuk Teknis Penyelesaian wicara oleh Majelis Desa Pakraman (MDP) Bali). Bahan hukum primer tersebut didukung bahan hukum sekunder meliputi Naskah Akademik RUU Penanganan Konflik Sosial serta literatur-literatur hukum yang relevan untuk menganalisis permasalahan yang diajukan dalam penelitian ini.

Teknik pengumpulan bahan hukum adalah teknik studi dokumen dengan melakukan pencatatanpencatatan atau memfotocopy informasi dari hbahan hukum yang diperlukan, Selanjutnya informasi yang terkumpul diolah dan dianalisis dengan teknik-teknik penafsiran dan konstruksi hukum yang relevan kemudian disajikan scara deskriptif analitis.

\section{HASIL DAN PEMBAHASAN 3.1 Latar Belakang Terjadinya Sengketa Adat}

Dalam rangka merumuskan mekanisme ideal penyelesaian sengketa adat sesuai dengan konsep kekinian, harus ditempatkan pada situasi saat ini yakni terjadinya proses perubahan sosial sebagai penyebab konflik yang secara cepat tengah terjadi karena pengaruh globalisasi, dan adanya kepentingan-kepentingan yang bertentangan. ${ }^{6}$ Wirta Griadhi menyatakan bahwa, sengketa adat

6 Ali Mandan, 1986, Kelas dan Konflik Kelas dalam Masyarakat Industri, Sebuah Analisa Kritik, Cet. 1, Rajawali Press, Jakarta., hlm.21. di lingkungan masyarakat hukum adat disebabkan karena adanya penyimpangan dari norma adat yang berlaku, dan juga disebabkan oleh perbedaan pandangan para pihak tentang hal-hal yang menjadi obyek konflik. ${ }^{7}$ Perbedaan pandangan para pihak disebabkan karena adanya perubahan tatanan sosial dan pengaruh perkembangan globalisasi, sehingga masyarakat adat tidak mampu menyelesaikan secara otonom sengketa adat yang terjadi.

Mengenai latar belakang terjadinya sengketa adat (konflik adat) adat, I Nyoman Sirtha menyatakan bahwa konfllik adat terjadi karena adanya perubahan sosial dan pergeseran nilai-nilai budaya dalam masyarakat. Hal itu dapat diidentifikasi dari perubahan-perubahan perilaku warga masyarakat. Lebih lanjut Sirtha menjelaskan bahwa ilmu pengetahuan dan teknologi yang berkembang dengan pesat menyebabkan kehidupan masyarakat menjadi semakin maju. Kehidupan masyarakat yang semakin maju tersebut menimbulkan pergeseran nilai-nilai budaya dalam masyarakat dimana kepentingan-kepentingan pribadi sering berbenturan dengan kepentingan masyarakat adat yang menimbulkan sengketa adat. ${ }^{8}$ Sarjana

\footnotetext{
I Ketut Wirta Griadhi, 2005, "Konflik Adat di Bali Suatu Studi Hukum dan Perubahan Sosial", tesis ProgramPasca Sarjana (S2) Ilmu Hukum Universitas Udayana, Denpasar, hlm. 156-157.

8 I Nyoman Sirtha, 2008, Aspek Hukum Dalam Konflik Adat di Bali, Udayana University Press, hlm. 75.
} 
lain, I Gede Suartika menengarai eforia reformasi turut mempengaruhi maraknya sengketa adat di desa pakraman belakangan ini karena gerakan reformasi yang terjadi di tahun 1998 memberikan kebebasan berekspresi kepada masyarakat. ${ }^{9}$

\subsection{Mekanisme Tradisional Penye- lesaian Sengketa Adat}

Secara kelembagaan, masyarakat adat di Bali diwadahi dalam satu lembaga tdradisional yang disebut desa pakraman. Desa pakraman adalah kesatuan masyarakat hukum adat yang bersifat teritorial dan mempunyai otonomi, yaitu kekuasaan mengurus rumah tangganya sendiri. Menurut I Ketut Sudantra, isi otonomi desa pakraman adalah adalah seperangkat hak atau kekuasaan yang meliputi: (1) kekeuasaan membentuk hukumnya sendiri (awig-awig); (2) kekuasaan melaksanakan pemerintahannya sendiri (oleh prajuru), (3) kekuasaan melakukan pengamanan sendiri (oleh pecalang); dan (4) kekuasaan melaksanakan peradilan sendiri (oleh prajuru melalui sangkepan/ paruman). Walaupun otonomi desa pakraman dijamin oleh Pasal 18B ayat (2) UUD 1945, namun Sudantra juga mengakui bahwa otonomi desa pakraman bukanlah otonomi tanpa batas, melainkan semi otonom karena pelaksanaannya harus sesuai dengan perkembangan jaman dan prinsip$9 \quad$ I Gede Suartika, 2010, Anatomi Konflik Adat Di Desa Pakraman dengan Cara Penyelesaiannya, Udayana University Press, Denpasar, hlm. v.
Vol. 5, No. $2: 321$ - 336 http://ojs.unud.ac.id/index.php/jmhu prinsip negara kesatuan Republik Indonesia $^{10}$.

Dengan adanya kekuasaan melaksanakan peradilan sendiri yang dimiliki oleh desa pakraman, maka sesungguhnya dalam masyarakat adat di Bali telah ada mekanisme tradisional dalam penyelesaian sengketa adat, yaitu penyelesaian internal di desa pakraman itu sendiri. I Ketut Sudantra dalam salah satu penelitiannya juga menemukan bahwa mekanisme penyelesaian sengketa memang sudah diatur dalam peraturanperaturan adat yang dibuat oleh desa pakraman di Bali. Peraturan-peraturan adat tersebut lazim disebut awig-awig yang mengatur kehidupan anggota kesatuan masyarakat hukum adat yang bersangkutan. Dalam awig-awig desa pakraman terdapat satu bab (sarga) khusus yang mengatur penyelesaian sengketa (wicara) di bawah judul: Wicara lan Pamidanda. Dalam bab ini diatur mekanisme penyelesaian sengketa, terutama tentang instansi yang berwenang menyelesaikan sengketa, dan sepintas mengenai mengenai mekanismenya dan asas-asas yang digunakan dalam menyelesaikan sengketa ${ }^{11}$.

10 I Ketut Sudantra, dkk., 2015, "Identifikasi Lingkup Isi dan Batas-batas Otonomi Desa Pakraman dalam Hubungannya dengan Kekuasaan Negara", Jurnal Magister Hukum Udayana, Vol 4 No. 1 Mei 2015, hlm.25.

11 I Ketut Sudantra dan Ni Nyoman Sukerti, 2014, "Pengaturan Peradilan Adat dalam Awig-awig Desa Pakraman: Studi Pendahuluan tentang Eksistensi Peradilan Adat dalam Kesatuankesatuan Masyarakat Hukum Adat Desa Pakraman", Jurnal Magister Hukum Udayana, Vol. 6 No 2 Tahun 2014, hlm. 313. 
Mengenai instansi yang berwenang menyelesaikan sengketa adat yang terjadi di wilayah desa pakraman sudah sangat jelas, yaitu prajuru (kepala adat) sesuai dengan jenjangnya. Apabila sengketa itu terjadi di tingkat banjar (bagian dari desa pakraman), maka instansi yang menyelesaikannya adalah prajuru banjar (klihan banjar), sedangka sengketa yang terjadi di tingkat desa pakraman atau tidak dapat diselesaikan di tingkat banjar, instansi yang berwenang menyelesaikannya adalah prajuru desa pakraman (bendesa). Hanya saja, mekanisme penyelesaian sengketa ternyata tidak diatur secara lengkap dan jelas dalam awig-awig ${ }^{12}$. Kondisi tersebut juga diakui oleh Wayan P. Windia yang menyatakan bahwa lembaga-lembaga tradisional (desa pakraman, banjar, subak, dan lain-lain) memang sudah memiliki peraturan adat (awig-awig) yang dapat dipandang sebagai hukum materiil, tetapi bagaimana peraturan tersebut dilaksanakan, lembaga tersebut belum memiliki hukum formil (hukum acara) yang memadai. Akibatnya, terjadi beberapa kemungkinan dalam penerapan awig-awig.; sanksi adat sering dijatuhkan tidak sesuai dengan berat-ringannya kesalahan; sanksi adat dijatuhkan melalui suara terbanyak yang bersifat spontanitas atau sesaat (suryak siu, briuk siu ata $u$ briuk semanggul); penerapan hukum didasari oleh perasaan

$\overline{12 \quad \text { Ibid., hlm. } 315 .}$ sentimen pribadi dari orang-orang tertentu yang kebetulan berpengaruh. Dengan demikian, menurut Windia, peranan prajuru sangat penting. Apabila prajuru brersungguh-sungguh ingin menciptakan bersama, maka masyarakat yang dipimpinnya akan damai; sebaliknya apabila prajuru menghendaki seseorang dihukum berat karena sentimen pribadi, maka tidak baik akibatnya bagi masyarakat yang dipimpinnya ${ }^{13}$

Apabila uraian di atas dikaitkan dengan data pada Tabel 1 di atas, maka menjadi sangat logis untuk menyatakan bahwa mekanisme tradisional yang tersedia tidak selalu efektif dalam penyelesaian sengketa adat. Oleh karena itu, menjadi semakin penting dan urgen untuk menemukan dan merumuskan mekanisme ideal dalam penyelesaian sengketa adat di Bali.

\subsection{Faktor-faktor yang Mempengaruhi Efektivitas Penyelesaian Sengketa Adat di Bali \\ Secara teoritis, efektifitas hukum} tidak melulu hanya dipengaruhi oleh satu faktor tertentu saja, sebab seperti dikatakan oleh Lawrence M. Friedman, bekerjanya hukum dalam masyarakat itu ibarat mesin yang bekerja dalam suatu sistem. Sistem hukum sendiri terdiri dari tiga komponen, yaitu (1) komponen substansi hukumnya (legal

13 Wayan P. Windia dan Ketut Sudantra, 2006, Pengantar Hukum Adat Bali, Lembaga Dokumentasi Dan Publikasi Fakultas Hukum Universitas Udayana Denpasar, hlm.150-153. 
substance) yaitu hukumnya sendiri atau norma/kaidah hukumnya; (2) komponen struktur hukumnya (legal structure) yaitu pelaksana (penegak) hukumnya; serta (3) komponen budaya hukum (legal culture), yaitu sikap dan perilaku hukum dari warga masyarakat ${ }^{14}$. Berdasarkan teori Friedman ini sistem hukum akan bekerja dengan efektif apabila komponen-komponen sistem hukum tersebut berfungsi dengan bauik dan bekerja secara harmonis; sebaliknya apabila ada salah satu komponen tidak berfungsi dengan baik maka sistem hukum tersebut tidak akan mampu bekerja secara efektif.

Tiga komponen sistem hukum di atas kemudian lebih dirinci lagi oleh Soerjono Soekanto dan digunakan untuk mengidentifikasi faktor-faktor yang mempengaruhi efektifitas penegakan hukum, yaitu: (1) faktor hukumnya sendiri; (2) faktor penegak hukum; (3) faktor sarana dan fasilitas penegakan hukum; (4) faktor masyarakat; dan (5) faktor kebudayaan. Menurut Soerjono Soekanto, kelima faktor di atas saling berkaitan dengan eratnya, karena merupakan esensi dari penegakan hukum, juga menjadi tolok ukur daripada efektivitas penegakan hukum $^{15}$.

TeoriSistemhukumdariFriedman dan teori efektivitas penegakan hukum

14 Lawrence M. Friedman, 1969, The Legal System: A Social Science Perspektive, Russel Sage Foundation, New York, hlm.16,

15 Soerjono Soekanto, 2012, Faktor-Faktor yang Mempengaruhi Penegakan Hukum, Rajawali Pers, Jakarta, hlm. 8-9. dari Soerjono Soekanto di atas dapat diadopsi untuk menganalisis faktorfakor yang mempengaruhi efektifitas penyelesaian sengketa adat. Dari uraian sebelumnya, tampaknya sektor substansi hukum dapat ditunjuk sebagai sektor yang cukup kritis dalam mekanisme penyelesaian sengketa adat, sebab peraturan-peraturan adat yang dituangkan dalam awig-awig desa pakraman belum cukup memadai untuk dapat digunakan untuk menyelesaikan sengketa adat, apalagi dalam kondisi masyarakat yang semakin kompleks dewasa ini dan ke depan. Walaupun para kepala adat (prajuru) sudah diberikan wewenang oleh hukum (awig-awig) untuk menyelesaikan sengketa-sengketa adat yang terjadi di wilayah desa pakraman, tetapi dengan tidak adanya hukum acara (hukum formil) yang memadai maka hal itu akan menyulitkan para pelaksana hukum (prajuru) dalam melaksanakan fungsinya menyelesaikan sengketa adat secara efektif.

Sektorkritis lainnya adalah sektor pelaksana hukumnya. Dalam kondisi masyarakat yang semakin komplek dan terus berubah, dituntut kemampuan dan kualitas kepala adat (prajuru) yang mumpuni untuk dapat melaksanakan fungsinya menyelesaikan sengketa adat di wilayahnya. Tuntutan demikian tentu tidak dapat dipenuhi oleh semua kepala adat yang jumlahnya ribuan di Provinsi Bali mengingat kondisi masing-masing desa pakraman sangat bervariatif dilihat dari kualitas 
sumber daya manusianya; sistem rekrutmen kepala adat yang masih ada berdasarkan keturunan, dan lain-lain. Pada daerah-daerah yang kemampuan dan kualitas prajuru desa pakramannya lemah, tentu tidak banyak yang dapat diharapkan untuk mampu menyelesaikan sengketasengketa yang terjadi di wilayahnya secara efektif. Di beberapa daerah kabupaten di Bali, memang sudah lama terbangun mekanisme penyelesaian sengketa melalui Tim Terpadu yang khusus berfungsi untuk menyelesaikan sengketa-sengketaadatyang tidak dapat diselesaikan di tingkat desa, seperti misalnya yang berlaku di Kabupaten Gianyar $^{16}$. Saat ini, semangat tim terpadu tersebut terakomodir dalam Satuan Tugas Penyelesaian Konflik Sosial yang keanggotaannya terdiri dari unsur pemerintah dan masyarakat, sebagaimana yang diatur dalam Undang-undang Nomor 7 Tahun 2012 tentang Penanganan Konflik Sosial. Berdasarkan Pasal 47 undang-undang tersebut, pada level kabupaten/kota, unsur pemerintah daerah yang duduk dalam Satuan Tugas adalah: (a) Bupati/ Wali kota; (b)Ketua DPRD kabupaten/ kota; (c) instansi Pemerintah dan/

16 Tim ini bernama: Tim Penanganan Kasuskasus Adat/Sosial di Kabupaten Gianyar, dibentuk berdasarkan Keputusan Bupati Lihat: Ida Bagus Nyoman Rai, 2010, "Penyelesaian Konflik Adat: Pengalaman di kabupaten Gianyar", dalam I Ketut Sudantra dan AA Gede Oka Parwata,(ed): Wicara lan Pamidanda, Pemberdayaan Desa Pakraman dalam Penyelesaian Perkara di Luar Pengadilan, Udayana University Press, hlm. 175. atau satuan kerja perangkat daerah sesuai dengan kebutuhan; (d) Kepala Kepolisian Resor; (e) Komandan Distrik Militer/komandan satuan unsur TNI; dan (f) Kepala Kejaksaan Negeri; sedangkan unsur masyarakat terdiri dari: (a) tokoh agama; (b) tokoh adat; (c) tokoh masyarakat; (d) penggiat perdamaian; dan (e) wakil pihak yang berkonflik. Unsur masyarakat harus memperhatikan keterwakilan perempuan sekurangkurangnya $30 \%$ (tiga puluh persen). Pembentukan satuan tugas dilakukan oleh pejabat sesuai tingkatannya, di tingkat kabupaten/kota dilakukan bupati/walikota dan di tingkat provinsi oleh gubernur.

Adanya Tim Terpadu (Satuan Tugas) tersebut ternyata belum memberikan makna yang signifikan bagi efektifitas penyelesaian sengketa adat di Bali. Indikasi ini dapat dibaca dari fakta yang tersaji pada Tabel 1: dari 35 kasus yang terekam dalam data Polda Bali, hanya 5 kasus yang berhasil diselesaikan dengan baik.

Mengenai faktor sarana dan fasilitas pasti berpengaruh bagi efektivitas penyelesaian sengketa adat, walaupun diakui bahwa penulis tidak mempunyai cukup data untuk mendukung pernyataan ini. Untuk membuktikan hal ini mesti dilakukan penelitian secara empiris. Tetapi mesti dipahami, untuk menggerakkan sebuah tim yang besar dalam suatu kegiatan, semisal Satuan Tugas yang terdiri banyak pejabat dan tokoh, tentu 
dibutuhkan sarana dan fasilitas, paling tidak berupa anggaran yang memadai. Tanpa anggaran yang memadai, tentu tidak mungkin mengharapkan Satuan Tugas dapat berfungsi maksimal

.Dua faktor terakhir yang dikemukakan oleh Soerjono Soekanto, yakni faktor masyarakat dan kebudayaan, dapat diidentifikasi sebagai faktor yang sangat menentukan dalam penyeesaian sengketa adat. Sebab, sebagus apapun hukum yang tersedia dan sebagus apapun kuaalitas pelaksana hukumnya, apabila kondisi masyarakatnya tidak mendukung, maka penyelesaian sengketa adat akan gagal. Titik lemah kondisi sebagian masyarakatsekarangterletakpadasikap dan perilakunya yang mengabaikan nilai-nilai hukum adat, diantaranya nilai harmoni dalam kehidupan bersama. Dampak luas era globalisasi dan kemajuan ilmu pengetahuan dan teknologi menyebabkan pergeseran nilai-nilai budaya berupa melemahnya nilai-nilai kebersamaan (kekeluargaan) dan menguatnya nilai-nilai individualisme. Akibatnya, kepentingan-kepentingan individu menjadi lebih utama dibandingkan kepentingan masyarakat sehingga sering terjadi konflik kepentingan yang menimbulkan sengketa. Dalam penyelesaiannya pun, para pihak tidak lagi meletakkan kepentingan bersama (win-win solution) sebagai tujuan bersama dalam penyelesaian sengketa, melainkan kepentingan individulah yang utama sehingga para pihak akan selalu ngotot untuk memenangkan kepentingannya sendiri. Faktor inilah yang menyebabkan terjadinya kegagalan dalam penyelesaian sengketa adat.

\subsection{Mekanisme Ideal Penyelesaian Sengketa Adat di Bali Sesuai Dengan Konsep Kekinian}

Teori hegemoni dari Antonio Gramsci mengajarkan bahwa ....... "two basic concept to analysis of modern society : first, political society or the repressive aparatus of the state; and second, civil society private apparatus of hegemony, ${ }^{17}$ " artinya dua konsep dasar untuk menganalisis masyarakat modern: pertama, masyarakat politik atau aparatur represif negara; dan kedua, masyarakat sipil aparat pribadi hegemoni. Perangkat kerja pertama yang bernuansa law enforcemant; dan kedua, perangkat kerja yang mampu membujuk masyarakat beserta pranatapranata untuk taat pada mereka yang berkuasa melalui kehidupan beragama, pendidikan, kesenian dan bahkan juga keluarga. Dikaitkan dengan penyelesaian sengeta adat dalam rangka menjaga dan lelanggengkan stabilitas kehidupan bermasyarakat, maka penggunaan perangkat kerja yang bernuansa law enforcement dalam penyelesaian sengketa adatsepenuhnya menjadi kewenangan pemerintah, dalam hal ini melalui fungsi-fungsi

\footnotetext{
Antonio Gramsci, 2002, Critical Assessments Of Leading Political Philosopher, edited by, James Martin, 11 New Fetter Lane, London.,hlm. 181.
} 
penegakan hukum dengan berpedoman pada hukum nasional; sedangkan penggunaan perangkat kerja yang mampu membujuk masyarakat beserta pranata-pranatanya dapat menggunakan model penyelesaian sengketa yang mengedepankan pemanfaatan kearifan lokal.

Dalam kontek ini penting dikemukakan pandangan Wayan $\mathrm{P}$. Windia, yang menyatakan bahwa penyelesaian sengketa adat dapat menggunakan tiga cara, yaitu: (1) melalui penyelesaian dengan mekanisme internal yang dilaksanakan oleh perangkat atau prajuru adat, secara berjenjang sesuai dengan struktur kelembagaan organisasi masyarakat adat; (2) melalui penyelesaian dengan mekanisme eksternal, yaitu dengan melibatkan pemerintah, seperti kepolisian, kejaksaan dan pengadilan; dan (3) melalui penyelesaian dengan mekanisme gabungan, yaitu penyelesaian konflik adat secara terkoordinasi antara perangkat prajuru desa dengan lembaga pemerintah dan organisasi yang bernafaskan agama Hindu ${ }^{18}$.

Berdasarkan teori hegemoni dan pendapat Windia di atas, dapat diuraikan mekanisme ideal dalam penyelesaian sengketa adat. Pertama, sedapat mungkin sengketa adat

18 Wayan P. Windia, 2010, "Menyelesaikan Konflik Adat", dalam I Ketut Sudantra dan AA Gede Oka Parwata (ed) Wicara lan Pamidanda Wicara lan Pamidanda, Pemberdayaan Desa Pakraman dalam Penyelesaian Perkara di Luar Pengadilan, Udayana University Press, Denpasar, hlm. 274. diselessaikan dengan menggunakan mekanisme internal berbasis kearifan lokal. Mekanisme ini tepat digunakan terutama pada kesatuankesatuan masyarakat hukum adat desa pakraman di daerah perdesaan yang kehidupannya masih sederhana. Pada umumnya, pada masyarakat perdesaaan, kehidupan masyarakatnya relatif masih sederhana dan masih setia dan taat kelembagaan tradisional dan masih menjunjung tinggi nilainilai hukum adat, terutama nilai-nilai kebersamaan. Seperti dikemukakan oleh Von Benda Beckman, penyelesaian sengketa pada masyarakat yang masih sederhana, dimana hubungan kekerabatan dan kelompok masih kuat, maka pilihan institusi untuk penyelesaian sengketa atau konflik yang terjadi diarahkan kepada institusi yang bersifat kerakyatan (folk institutions), karena institusi penyelesaian sengketa atau konflik yang bersifat tradisional bermakna sebagai institusi penjaga keteraturan dan pengembalian keseimbangan magis dalam masyarakat. ${ }^{19}$.

Model penyelesaian internal yang disebutkan oleh Windia sangat tepat digunakan dalam kondisi masyarakat dengan ciri-ciri seperti di atas. Penyelesaian secara berjenjang sesuai mekanisme tradisional melalui

\footnotetext{
19 H.LL.Syapruddin, 2014, "Mekanisme Penyelesaian Sengketa Menurut Kearifan Lokal", Makalah disampaikan pada pelatihan dan pembekalan Pengurus (mediator) Bale Sangkep Desa (BSD) Desa Sintung dan Desa Kekait, Fakultas Hukum Universitas Muhammadiyah Mataram, NTB, 30 April.
} 
prajuru adat akan memberi peluang terjadinyapenyelesaian sengketasecara damai karena penyelesaian secara adat dilakukan secara musyawarah mufakat dengan mengedepankan asas rukun, laras dan patut sebagaimana dikemukakan oleh Moh Koesnoe. ${ }^{20}$ Wujud kongkrit penyelesaian sengekata adat dengan internal ini dapat dirumuskan sebagai berikut:

a. Sengketa adat yang terjadi ditingkat banjar, diselesaikan melalui mekanisme internal yang tersedia di banjar yang bersangkutan;

b. Apabila sengketa tidak dapat diselesaikan di tingkat banjar, maka sengketa diselesaikan di tingkat desa pakraman sesuai mekanisme awig-awig yang berlaku di desa pakraman yang bersangkutan;

c. Apabila sengketa tidak dapat diselesaikan di tingkat desa pakraman, maka sengketa adat dapat diselesaikan oleh Majelis Desa Pakraman (MDP) melalui mekanisme penyelesaian yang telah ditentukan oleh MDP. Saat ini, penyelesaian sengketa (wicara) melalui MUDP Provinsi Bali telah diatur dalam Keputusan Majelis Utama Desa Pakraman Bali Nomor : 002/ Skep/MDP Bali/IX/2011 tentang Petunjuk Pelaksanaan dan Petunjuk Teknis Penyelesaian

20 Moh. Koesnoe, 1979, Catatan-Catatan Terhadap Hukum Adat Dewasa Ini, Airlangga University Press, Surabaya, hlm. 45.
Vol. 5, No. 2 : 321 - 336

http://ojs.unud.ac.id/index.php/jmhu

wicara oleh Majelis Desa Pakraman (MDP) Bali.

Sebagaimana telah diuaraikan di atas, dampak kekuatan global yang telah melanda dunia telah banyak mengubah kondisi masyarakat, termasuk masyarakat adat di Bali. Seperti dikatakan oleh Moh. Koesne, ciri-ciri kekuatan global itu adalah mengangungkan prinsipprinsip individualistik, sekuleristik, materialistik, dan hedonis yang menghendaki setiap orang bersaing satu dengan lainnya untuk mendapatkan kemakmuran materiilnya agar menjadi kaya, tenar dan berkuasa ${ }^{21}$. Di banyak tempat di Bali, terutama di daerahdaerah perkotaan, akibat pengaruh keluatan global yang melanda itu nilai-nilai kebersamaan (persaudaraan) menjadi semakin melemah, sebaliknya nilai-nilai individualistik semakin menguat. Indikasi dari pergeseran tersebut tampak dari sikap dan perilaku warga masyarakat yang tidak lagi menempatkan kepentingan bersama sebagai tujuan, melainkan menempatkan kepentingan pribadi (individu) yang harus diperjuangkan mati-matian.

$$
\text { Pengagungan nilai-nilai }
$$
individualistik mempengaruhi budaya hukum masyarakat dalam menghadapi dan menyelesaikan masalahnya, yaitu selalu berjuang untuk memenangkan kepentingannya sendiri daripada

\footnotetext{
21 Moh. Koesnoe, 1996, Hukum Adat (Dalam Alam Kemerdekaan Nasional dan Persoalannya Menghadapi Era Globalisasi), Ubhara Press, hlm. 137.
} 
menjaga dan memelihara kepentingan bersama dalam kehidupan bermasyarakat. Dengan demikian, tujuan penyelesaian sengketa bukan lagi keharmonisan dalam kehidupan bersama, melainkan untuk memenangkan hak-hak individual (kepentingan sendiri) sehingga sangat sulit diselesaikan secara damai. Dalam kondisi demikian, maka penyelesaian sengketa adat harus dilakukan dengan menggunakan mekanisme eksternal, yaitu penyelesaian dilakukan oleh pemerintah berdasarkan hukum nasional.

Dalam perspektif hukum nasional, penyelesaian sengketa adat yang mengarah kepada konflik sosial dapat menggunakan mekanisme yang disediakan oleh Pasal 41 UndangUndang Nomor. 7 Tahun 2012 yang intinya menyatakan bahwa :

1. Penyelesaian konflik dilaksanakan oleh Pemerintah dengan mengedepankan Pranata Adatdan/atauPranataSosialyang ada dan diakui keberadaannya;

2. Dalam hal penyelesaian konflik melalui mekanisme Pranata Adat dan/atau Pranata Sosial tidak dapat diselesaikan, maka penyelesaian konflik dilakukan oleh Satuan Tugas Penyelesaian Konflik Sosial.

Dengan demikian, mekanisme ideal yang diharapkan oleh Pasal 41 Undang-undang Nomor 7 Tahun 2012 adalah mekanisme penyelesaian sengketa adat doleh Pemerintah dengan mengedepankan pranata adat/ atau pranata sosial. Hal ini mirip dengan mekanisme gabungan yang dikemukakan oleh Windia di atas. Hanya apabila pranataadat/atau pranata sosial tidak dapat menyelesaikan sengketa adat, maka penyelesaian sengketa adat dilakukan oleh Satuan Tugas Penyelesaian Konflik Sosial.

Sesuai Penjelasan Umum Undang-undang Nomor 7 tahun 2010, tujuan penanganan konflik adalah untuk: (1) menciptakan kehidupan masyarakat yang aman, tenteram, damai, dan sejahtera; (2) memelihara kondisi damai dan harmonis dalam hubungan sosial kemasyarakatan; (3) meningkatkan tenggang rasa dan toleransi dalam kehidupan bermasyarakat dan bernegara; (4) memelihara keberlangsungan fungsi pemerintahan; (5) melindungi jiwa, harta benda, serta sarana dan prasarana umum; (6) memberikan pelindungan dan pemenuhan hak korban; serta (7) memulihkan kondisi fisik dan mental masyarakat. Untuk dapat mencapai tujuan tersebut, undangundang mengatur penanganan konflik sosial yang dilakukan dalam 3 (tiga) tahapan, yaitu: pertama, pencegahan konflik melalui upaya pemeliharaan kondisi damai dalam masyarakat, mengembangkan penyelesaian sengketa secara damai, meredam potensi konflik; dan membangun sistem peringatan dini. Kedua, penghentian konflik melalui upaya penghentian 
kekerasan, penetapan staus keadaan konflik, tindakan darurat penyelematan dan perlindungan korban, dan/atau pengerahan dan penggunaan kekuatan meliter. Ketiga, penanganan konflik pasca konflik melalui upaya pemulihan pascakonflik secara terencana, terpadu, berkelanjutan, dan terukur melalui upaya rekonsiliasi; rehabilitasi; dan rekonstruksi.

\section{PENUTUP}

\subsection{Simpulan}

Berdasarkan uraian di atas, akhirnya sebagai penutup tulisan ini dapat disimpulkan sebagai berikut:

1. Faktor-faktor yang mempengaruhi efektifitas penyelesaian sengketa adat di Bali meliputi: (a) faktor hukumnya yang belum memadai; (b) faktor pelaksana hukum yang kemampuan dan kualitasnya masih lemah dalam penyelesaian sengketa adat; (c) faktor sarana dan fasilitas pendukung yang kurang memadai; serta (d) faktor masyarakat yang mengabaikan nilai-nilai hukum adat; serta (e) nilai-nilai budaya masyarakat yang mulai bergeser, yang mulai meninggalkan nilainilai keberdsamaan dan mengagungkan nilai-nilai individualistic.

2. Mekanisme yang ideal dalam menyelesaikan sengketa adat di Bali sesuai dengan konsep kekinian adalah tetap mengedepankan penyelesaian sengketa adat melaluimekanisme internal berbasis kearifan lokal. Apabila mekanisme internal tersebutgagal,makapenyelesaian sengketa adat dapat dilakukan dengan mekanisme eksternal, yaitu penyelesaian konflik dilakukan oleh Pemerintah dengan mengedepankan Pranata Adat dan/atau Pranata Sosial yang ada dan diakui keberadaannya. Dalam hal mekanisme inipun gagal, maka penyelesaian konflik dilakukan oleh Satuan Tugas Penyelesaian Konflik Sosial yang dibentuk oleh Pemerintah.

\subsection{Saran}

1. Diperlukan adanya sosialisasi kepada instansi yang terlibat dalam satuan tugas terpadu, terkait dengan mekanisme, ketentuan dan peraturan yang terkaitdalamrangkapenyelesaian sengketa adat.

2. Diperlukan upaya pembelajaran hukum adat baik melalui media formal maupun informal kepada masyarakat, sehingga mengerti dan memahami asas-asas yang berlaku di dalam hukum adat, dan mekanisme penyelesaian sengketa adat. 


\section{DAFTAR PUSTAKA}

\section{A. Literatur}

Ali Mandan, 1986, Kelas dan Konflik Kelas dalam Masyarakat Industri, Sebuah Analisa Kritik, Cet. 1, Rajawali Press, Jakarta

Friedman Lawrence M., 1969, The Legal System: A Social Science Perspektive, Russel Sage Foundation, New York.

Gramsci Antonio, 2002, Critical Assessments OfLeading Political Philosopher, edited by, James Martin, 11 New Fetter Lane, London.

Koesnoe Moh., 1979, Catatan-Catatan Terhadap Hukum Adat Dewasa Ini, Airlangga University Press, Surabaya

Moh. Koesnoe, 1996, Hukum Adat (Dalam Alam Kemerdekaan Nasional dan Persoalannya Menghadapi Era Globalisasi), Ubhara Press.

Mukti Fajar ND dan Yulianto Achmad, 2010, Dualisme Penelitian Hukum Normatif \& Empiris, Pustaka Pelajar, Yogyakarta.

Peter Mahmud Marzuki, 2013, Penelitian Hukum, Edisi Revisi, Kencana Prenada Media Group, Jakarta.

Rai Ida Bagus Nyoman, 2010, "Penyelesaian Konflik Adat: Pengalaman di kabupaten Gianyar", dalam I Ketut Sudantra dan AA Gede Oka Parwata,(ed): Wicara lan Pamidanda, Pemberdayaan Desa Pakraman
Vol. 5, No. 2 : 321 - 336 http://ojs.unud.ac.id/index.php/jmhu

dalam Penyelesaian Perkara di Luar Pengadilan, Udayana University Press.

Sirtha Nyoman, 2008, Aspek Hukum Dalam Konflik Adat di Bali, Udayana University Press.

Suartika I Gede, 2010, Anatomi Konflik Adat Di Desa Pakraman dengan Cara Penyelesaiannya, Udayana University Press, Denpasar

Sudantra I Ketut, 2010, "Peranan Desa Pakraman Dalam Penyelesaian Perkara di Luar Pengadilan". Dalam I Ketut Sudantra, dan A.A. Gede Oka Parwata (ed.): Wicara Lan Pamidanda, Udayana University Press, Denpasar.

Sudantra I Ketut dan Ni Nyoman Sukerti, 2014, "Pengaturan Peradilan Adat dalam Awigawig Desa Pakraman: Studi Pendahuluan tentang Eksistensi Peradilan Adat dalam Kesatuankesatuan Masyarakat Hukum Adat Desa Pakraman", Jurnal Magister Hukum Udayana, Vol. 6 No 2 Tahun 2014.

Sudantra I Ketut, dkk., 2015, "Identifikasi Lingkup Isi dan Batas-batas Otonomi Desa Pakraman dalam Hubungannya dengan Kekuasaan Negara", Jurnal Magister Hukum Udayana, Vol. 4 No. 1 Mei 2015

Soerjono Soekanto, 2012, FaktorFaktor yang Mempengaruhi Penegakan Hukum, Rajawali Pers, Jakarta, 
Surnal E-ISSN 2502-3101
Magister Hukum Uddayana
P-ISN 2302-528X Juli 2016

(UDAYANA MASTER LAW JOURNAL)

Syapruddin H.LL, 2014, "Mekanisme

Penyelesaian Sengketa Menurut

Kearifan Lokal", Makalah disampaikan pada pelatihan dan pembekalan Pengurus (mediator)

Bale Sangkep Desa (BSD)

Desa Sintung dan Desa Kekait,

Fakultas Hukum Universitas

Muhammadiyah Mataram, NTB, 30 April.

Windia Wayan P., 2010, "Menyelesaikan Konflik Adat", dalam I Ketut Sudantra dan AA Gede Oka Parwata (ed) Wicara lan Pamidanda Wicara lan Pamidanda, Pemberdayaan Desa Pakraman dalam Penyelesaian Perkara di Luar Pengadilan, Udayana University Press, Denpasar, h. 274.

Windia Wayan P. dan Ketut Sudantra, 2006, Pengantar Hukum Adat Bali, Lembaga Dokumentasi Dan Publikasi Fakultas Hukum Universitas Udayana Denpasar.

Wirta Griadhi I Ketut, 2005, "Konflik Adat di Bali Suatu Studi Hukum dan Perubahan Sosial", tesis Program Pasca Sarjana (S2) Ilmu Hukum Universitas Udayana, Denpasar.

\section{B. Peraturan:}

Undang-Undang Republik Indonesia

Nomor 7 Tahun 2012 tentang penanganan konflik sosial, Lembaran Negara Republik Indonesia Tahun 2012, No. 116.

Tambahan Lembaran Negara
Vol. 5, No. $2: 321$ - 336 http://ojs.unud.ac.id/index.php/jmhu

Republik Indonesia Nomor 5315. Sekretariat Negara. Jakarta.

Keputusan Majelis Utama Desa Pakraman Bali Nomor : 002/ Skep/MDP Bali/IX/2011 tentang Petunjuk Pelaksanaan dan Petunjuk Teknis Penyelesaian wicara oleh Majelis Desa Pakraman (MDP) Bali.

\section{Bahan Lain:}

Data Pemetaan Pemasalahan Adat, Tapal Batas Dan Pemekaran Desa Pakraman Diwilayah Bali Tahun 2000 - 2014, Dit Intelkam Polda Bali, Denpasar.

Data Kasus Konflik Sosial Bulan Maret Tahun 2014, Biro Operasi Polda Bali, Denpasar. 